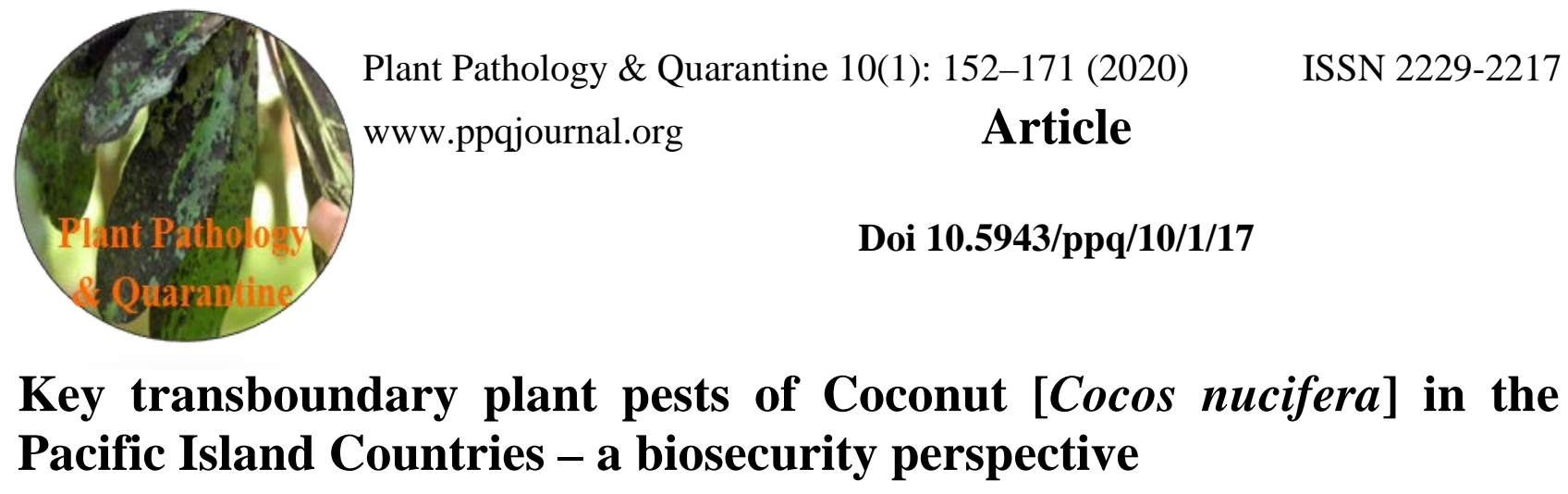

\title{
Datt $\mathbf{N}^{1}$, Gosai $\mathbf{R C}^{1}$, Ravuiwasa $\mathrm{K}^{2}$ and Timote $\mathrm{V}^{3}$
}

${ }^{1}$ Biosecurity Authority of Fiji, Suva, Fiji

${ }^{2}$ Fiji National University, Nausori, Fiji

${ }^{3}$ Pacific Community, Suva, Fiji

Datt N, Gosai RC, Ravuiwasa K, Timote V 2020 - Key transboundary plant pests of Coconut [Cocos nucifera] in the Pacific Island Countries - a biosecurity perspective. Plant Pathology \& Quarantine 10(1), 152-171, Doi 10.5943/ppq/10/1/17

\begin{abstract}
The movement of plant pests and diseases from one continent or country to another bypassing physical boundary is as ancient a menace as the drift of people themselves. Many of these species pose a direct threat to food security with progressive socio-economic perils affecting the livelihoods of people. The National Plant Protection Organisation of a country is vested with legislative powers to prevent the incursion of such species through the implementation of proactive measures such as risk assessments, monitoring, surveillance and controlling human-aided pathways. The unfortunate event of an unwanted incursion brings with it challenges of early detection and immediate implementation of eradication measures which are further compounded by capability gaps and funding constraints. The success of eradication is more than often determined by quick execution of appropriate emergency response measures and flexibility to scale operations when needed. Even with extensive and exhaustive eradication efforts applied, many-a-times the National Plant Protection Organizations face unfavourable results. Coconut is an extremely important subsistence as well as an economic plant for almost all island nations in the Pacific. In this view, existing transboundary pests of coconut in the Pacific Islands basin, namely Coconut Rhinoceros Beetle-Guam biotype, Coconut Lethal Yellowing phytoplasma and the Coconut Cadang-Cadang viroid pose more than a significant threat to countries free of these pests and which have put regional National Plant Protection Organizations on high alert.
\end{abstract}

Key words - Cadang-cadang - Coconut Rhinoceros Beetle - Guam biotype - Lethal yellowing

\section{Introduction}

To correctly understand the concept of transboundary pests, a key distinction between standard yet easily inaccurately used terms must be made. The term "pest" has been defined in many contexts covering a spectrum of definitions from broader to confined perspectives. A simple online search is likely to yield the following: a pest is "any living stage of insects, mites, nematodes, slugs, snails, protozoa, bacteria, fungi, other invertebrate animals, parasitic plants, parasitic plant parts, viruses, any other similar organism, or any infectious substances that can injure, infect or damage any plants or plant products". On the other hand, the International Plant Protection Convention (IPPC 2007) - International Standard for Phytosanitary Measures 5 (ISPM 5) defines a pest as any species, strain or biotype of plant, animal or pathogenic agent injurious to 
plants or plant products. It should be noted that "plant pest" is sometimes used for "pest" in IPPC terms (FAO 2019).

Pests can further be classified or grouped and in relation to "plant quarantine", a "quarantine pest" is one that is of economic importance to an area but not yet present there or present but confined to one or few locations and under official control (FAO 2019). A pest can also be invasive or non-invasive in its behaviour in the environment (Jarošík et al. 2015). An invasive species is one not native to a defined area, and that spreads causing damage to the environment affecting the economy and human health whereas a non-invasive species in one that does not (Tobin 2018). The Convention on Biological Diversity (CBD) describes invasive species with added adjectives calling such organisms "invasive alien species" or IAS for short, the introduction or spread of which into a new location brings menace to biological diversity (CBD 1992). However, in the IPPC context, IAS are ones the establishment or spread of which threatens plant health or that by risk analysis have been shown to be injurious to plant life and productivity.

This paper will discuss important pests of coconut, Cocos nucifera (L.), in the context that fits into the definition of quarantine pests and invasive alien species, thereby referred to as "transboundary plant pests" (TPPs). TPPs can easily move across borders and are capable of establishing and spreading rapidly thereby important to many countries due to food security, trade and economic significance and the control or management of which requires coaction by regional or international partnerships (FAO 2001).

\section{Coconut and its transboundary plant pests in the Pacific Islands}

The coconut palm garners an almost godly status and is celebrated as the "tree of life" in the Pacific (Foale 2003). The multiple and versatile uses of the coconut tree can be best judged by this Indonesian saying: "there are as many uses for the coconut as there are days in the year" (Madison 2017). The mature kernel is used as food for both human and animal consumption; the shredded kernels are used for making sweets while the milk extract from the shredded kernel is used for cooking and flavouring dishes; further processing of the extracted milk yields oil which is used for cooking or as fuel (Ahuja et al. 2014). The water from immature nuts is drunk as a fresh beverage or used to make a variety of alcoholic and non-alcoholic drinks, whereas the jelly-like kernel is eaten raw. The sap extracted from trees can be converted into sugar or fermented into alcohol (Nanda1990, Prades et al. 2012).

The husk fibres from mature nuts are woven into ropes (Ali 2018) or made into coir (Hume 1949, Handreck 1993, Smith 1995) while the whole husks and shells are used as fuel for the fire. The dried leaves and fronds are also used as fuels (Sangamithra et al. 2013). Shells are used as containers for drinking and making decorative items and souvenirs whereas the green fronds are woven into baskets and mats or as thatching for dwellings while the midribs of leaflets are used as brooms (Raghavan 2010). More recently, coconut has been used commercially to make furniture, virgin coconut oil and additives in the production of other commercial goods (Belayachi et al. 2017, Kumar et al. 2018, Atoyebi et al. 2019). It is also used for herbal medicine and pharmacological purposes (Campbell-Falck et al. 2000, DebMandal \& Mandal 2011, Lima et al. 2015).

The above almost non-exhaustive list of why the coconut palm is so important is threatened by several TPPs within the Pacific Island Countries and Territories (PICTs) that pose an immediate risk to the food security and livelihoods of people in countries free of these TPPs (Freeman et al. 2010, PHAMA Plus 2019). These pests can easily be introduced through natural phenomenon; trade of goods hosting these pests or as contaminants in goods carried in the air and sea containers, vessels and aircraft; or by insect vectors (FAO 2020).

\section{Coconut Rhinoceros Beetle (CRB) - Oryctes rhinoceros}

CRB possibly originated in the Southeastern region of Asia covering Malaysia, Myanmar, Thailand, Indonesia, Vietnam, South China and the Philippines where palm plantations have been a critical source of basic resources for survival over many centuries (Catley 1969). This damaging 
beetles subsequently spread more widely to India, Sri Lanka, Mauritius, Maldives, the Reunion Islands and the Arabian Peninsula (Goonewardene 1958, Waterhouse \& Norris 1987). CRB is believed to have been introduced in rubber seedling pot plants from Ceylon (Sri Lanka) to the Pacific island of Upolu, Western Samoa in 1909 and then to have spread within the region through increased sea traffic during World War II (Nishida \& Evenhuis 2000). First CRB infestation is noted for Wallis in 1931, Tonga in 1951, Fiji in 1953 and Tokelau in 1963. In 1942, the infestation was noted in New Britain island of Papua New Guinea and Palau, further spreading to New Ireland and Manus islands 7of Papua New Guinea in 1952 (Gressitt 1953, Lever 1979, Bedford 1974).

As early as 2007, more severe infestations with very destructive effects on coconut palms was noted in Guam followed by Papua New Guinea in 2009, Hawaii in 2013, Palau in 2014 and the Solomon Islands in 2015 (Jackson \& Marshall 2017, Tsatsia et al. 2018). This damage was identified to be caused by a more aggressive strain of the CRB named as "CRB - Guam biotype" or "CRB-G" for short. The earlier known mild strain was differentiated as the "CRB - Pacific biotype" or "CRB-P". The new haplotype (or biotype) CRB-G was not detected until careful analysis and scrutiny of deoxyribonucleic acid (DNA) sequences from multiple samples (Marshall et al. 2016).

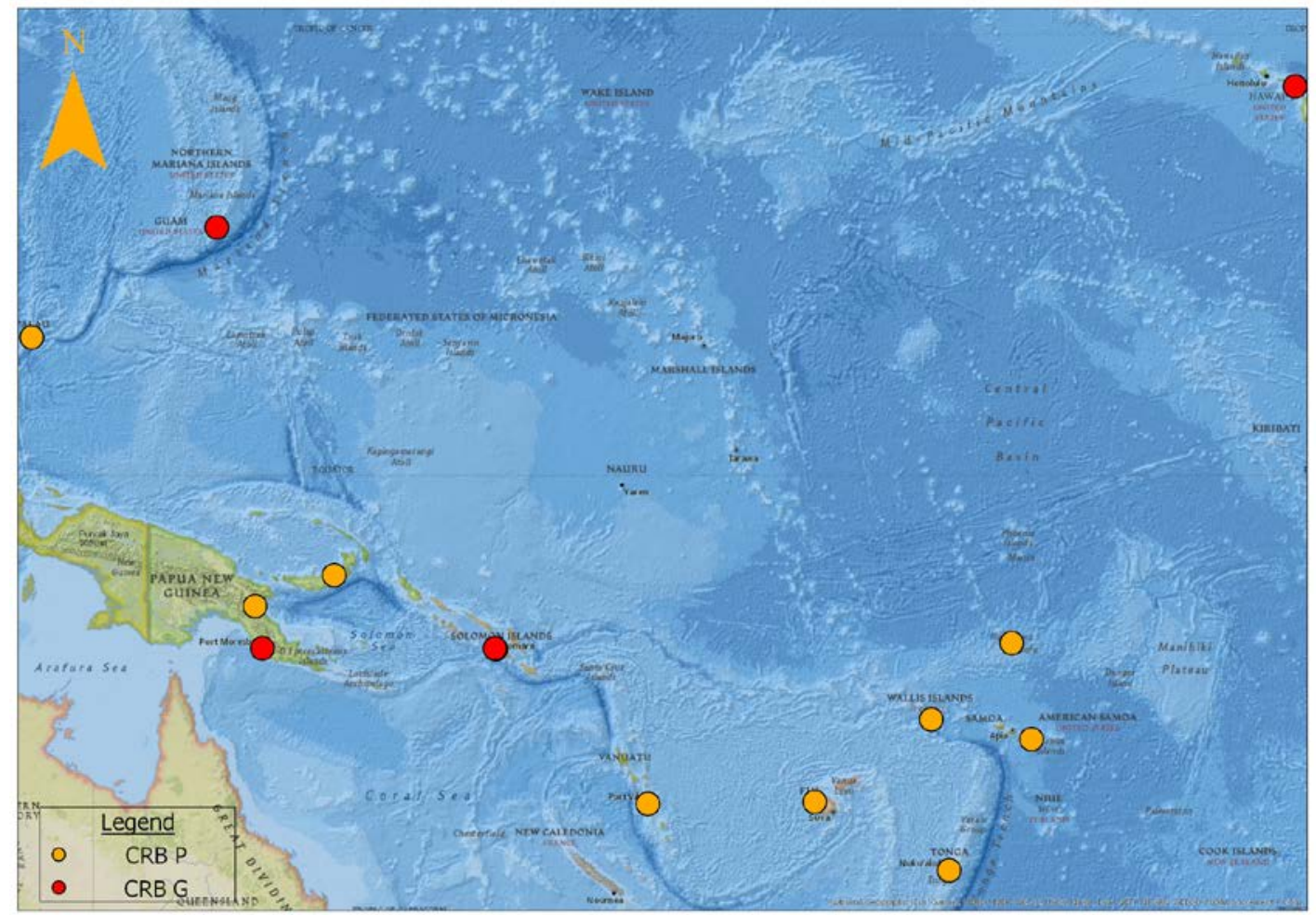

Fig. 1 - Illustration of CRB distribution in the Pacific. The yellow spots indicate the distribution of the Pacific strain while the red spots indicate the presence of the Guam biotype.

\section{CRB-Guam biotype}

Marshall et al. 2016 in their study determined that the new, more destructive damage seen in Guam was the result of infestation by a slightly genetically distinctive beetle compared to CRB-P, but of the same species. Using a restriction enzyme analysis of 523 bp cytochrome C oxidase I (COI) gene fragments digested by the enzyme MseI with a four base pair recognition sequence of 5' - TTAA - 3', it was detected that CRB-G has only six MseI sites compared to CRB-P which has seven in the same sequence length. This extra MseI enzyme site in CRB-P is located at base pair 286. However, it is noteworthy that currently there is no correlation study to suggest that the lesser number of MseI enzyme sites has an influence on the aggressive nature of CRB-G and its resistance to Oryctes rhinoceros nudivirus (OrNV). 


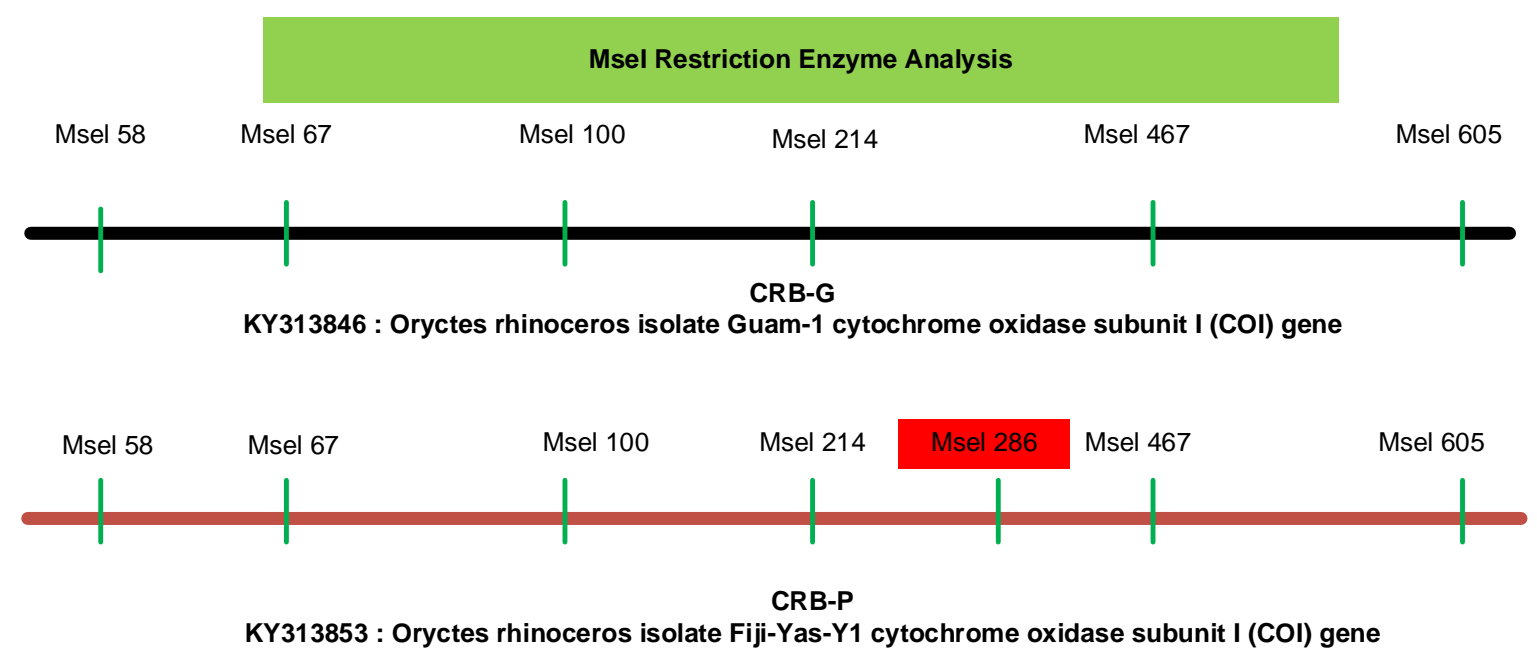

Fig. 2 - Diagrammatic representation of two aligned sequences to differentiate between CRB-P and CRB-G based on the polymerase chain reaction-restriction fragment length polymorphism (PCRRFLP) method.

\section{Biosecurity threat from CRB-G}

CRB-G quickly elevated to the level of an invasive pest due to its rapid spread from the Micronesian to Melanesian islands (Global Invasive Species Database 2019) and also because of the heavy damage it causes to coconut trees leading to complete annihilation of palms (tree death) and consequent loss of food, feed, coconut by-products and eventually revenue for farmers (Tsatsia et al. 2018). Additionally, the existing bio-control agent against CRB-P, the OrNV has been found to be ineffective against CRB-G. PICTs with established CRB-P populations, for example, Samoa, Tonga, Palau and Fiji noted the high severity and frequency of damage by this beetle, but with the introduction of OrNV, these damages drastically decreased. In the case of Guam, the release of OrNV was unsuccessful in controlling the damage, raising the possibility that the CRB population to have invaded Guam is tolerant or resistant to the commonly applied OrNV isolates (Marshall et al. 2016). The group noted that OrNV was present at high incidence in established populations of CRB-P, but generally absent from the invasive CRB-G populations via confirmation through polymerase chain reaction ("PCR") analysis. They further reported that the CRB-G from Guam was not susceptible to OrNV infection by oral delivery; however, death did occur when the virus was injected into the beetle.

CRB-G invasion has now occurred in five PICTs, namely, Guam, Papua New Guinea, Hawaii, Palau and the Solomon Islands in only ten years compared to CRB-P, which has not spread out of its known geographic distribution for over four decades (SPC 2017). Because of its economic importance, CRB (both biotypes) is a regulated or quarantine pest for all PICTs. Infestation leads to death of the palm trees, resulting in zero productivity affecting food security and livelihoods of the population, directly and indirectly, dependent on coconuts (Vaqalo et al. 2017). CRB is also able to survive on multiple hosts within the Arecaceae family and other plant species (Table 1); thus, the difficulty in eradicating this pest once introduced is multiplied (Anon 2017).

Table 1 A list of the main CRB host plants.

\begin{tabular}{ll}
\hline \multicolumn{1}{c}{ Scientific Name } & \multicolumn{1}{c}{ Common Name } \\
\hline Acanthophoenix rubra & Barbel palm \\
Corypha umbraculifera & Talipot palm \\
Pandanus tectorius & Tahitian screwpine \\
Agave sisalana & Sisal agave \\
Corypha utan & Buri palm \\
Phoenix dactylifera & Date palm \\
\hline
\end{tabular}


Table 1 Continued.

\begin{tabular}{ll}
\hline \multicolumn{1}{c}{ Scientific Name } & \multicolumn{1}{c}{ Common Name } \\
\hline Agave americana & American agave \\
Cyathea sp. & Tree fern \\
Phoenix sylvestris & Wild date palm \\
Aiphanes horrida & Ruffle palm \\
Dictyosperma album & Red palm \\
Pinanga sp. & Pinanga sp. \\
Ananas comosus & Pineapple \\
Dypsis pinnatifrons & Dypsis pinnatifrons \\
Pinanga insignis & Pinanga insignis \\
Areca sp. & Areca palm \\
Heterospathe elata var. palauensis & Palauensis \\
Pritchardia pacifica & Fiji fan palm \\
Areca catechu & Betel nut palm \\
Hydriastele palauensis & Hydriastele palauensis \\
Raphia farinifera & Raffia palm \\
Arenga sp. & Arenga palm \\
Hyophorbe lagenicaulis & Bottle palm \\
Raphia vinifera & Bamboo palm \\
Arenga pinnata & Sugar palm \\
Latania sp. & Latania sp. \\
Roystonea regia & Royal palm \\
Borassus sp. & Borassus palm \\
Livistona chinensis & Chinese fan palm \\
Saccharum sp. & Sugarcane \\
Borassus flabellifer & Palmyra palm \\
Metroxylon amicarum & Caroline ivory nut palm \\
Syagrus romanzoffiana & Queen palm \\
Caryota urens & Fish tail palm \\
Metroxylon sagu & Sago palm \\
Thrinax sp. & Thatch palm \\
Casuarina equisetifolia & Australian pine \\
Musa sp. & Banana \\
Verschaffeltia splendida & Seycelles stilt palm \\
Clinostigma samoense & Clinostigma samoense \\
Normanbya sp. & Normanbya sp. \\
Wodyetia bifurcata & Foxtail palm \\
Colocasia sp. & Taro \\
Nypa fruticans & Nipa palm \\
Corypha sp. & Corypha sp. \\
Oncosperma sp. & \\
\hline &
\end{tabular}

\section{Pathways for CRB-G introduction}

The 2013 incursion of CRB-G in Hawaii was first detected at a naval facility known as Joint Base Pearl Harbor-Hickam (HISC 2015). Thus, CRB-G was potentially introduced into Hawaii from Guam with the movement of military vessels and equipment between the two island archipelagos. The incursion in the Solomon Islands is linked to the Festival of Pacific Arts 2013 where the assumption has been that CRB-G might have come as a hitchhiker on agricultural produce brought by participants from Guam, Palau or PNG (Vaqalo et al. 2017). Taking these two examples into consideration, the likely high-risk pathways for CRB-G introduction into other PICTs free of this pest would be:

\section{Sea Vessels}

In most PICTs, wharf operations are on a 24-hour basis. Countries like Fiji have more than one major wharf and smaller quays which are international ports of entry for vessels and 
passengers, operating around the clock. CRB is understood to be a nocturnal species and greatly attracted to lights (SPC 2017). No doubt, the high beams on vessels and guiding lights on a wharf will be highly attractive to CRB. There are possibilities that adult CRB may fly and remain hidden on ships, especially on cargo or carrier vessels between container spaces. During discharge of these containers in subsequent ports-of-call, CRB can escape in the new environment, potentially establishing there and starting an incursion. Historically, islands in the Indian Ocean have been infested by this beetle hitchhiking on troopships during the first World War (Orian 1959 in Catley 1969) whereas the heavy sea traffic during World War II is thought to have introduced CRB to new islands in the Pacific (Catley 1969).

\section{Aircrafts}

Similar to wharves, many airports operate day and night continuously or at least late into the evening; lights on aircraft, airport runways and airport buildings attract insects of many kinds including CRB. Barney et al. 2006 have reported fascinating incidences of insects that were intercepted in aircraft arriving from international destinations. Secondly, it is common knowledge that many ports in the PICTs are vastly surrounded by palm trees. These areas provide perfect harbouring and breeding places for CRB, including CRB-G. Thus, the possibilities of CRB-G hitchhiking on aircraft is also certainly high. Bedford 1980 suggested that the increased air traffic alongside a surge in sea vessel movement during World War II aided CRB spread in the PICTs.

\section{Trade of CRB-G host products}

The trade of CRB-G host materials such as copra, copra meal, coconut choir, palm logs and compost manure also provides a pathway via which this pest can move from one country to another (SPC 2017). It is therefore prudent that the trade of such products always occurs on a bio-safe platform, and appropriate measures are implemented by the exporting country to ensure that the products are free of CRB - always remembering the fact that CRB goes through multiple life stages and the transfer of any of the developmental stages will lead to the successful establishment of the beetle (Nishida \& Evenhuis 2000). Importing countries should also set out special conditions for the import of CRB host products. Appropriate insect elimination treatments such as fumigation is highly recommended for the movement of these products (DAWE 2017).

\section{Unmonitored trade and movement}

All PICTs have a multitude of islands within their exclusive economic zone (EEZ). The enforcement of biosecurity laws on some of the remote islands may be absent due to human, financial and physical resource limitations. Secondly, it may be the case where out-lying islands of one country form boundaries with the outer islands of another country. There is always a high possibility of movement of people and goods within this expanse which could be a possible pathway for the introduction of TPPs. Barney et al. 2006, Liebhold et al. 2006 stress that the everincreasing rate of TPP invasions has largely been aided by human activities involving their mobility and trade. Not usually suspected, but due to the sheer closeness of some island countries including islands within a country, natural forces such as wind and water currents can be highly effective in the natural introduction of TPPs as well as in aiding in-country invasion (Burgiel \& Muir 2010). Organic matter, especially tree trunks and palm logs carried by waves to new areas, is a serious dispersal threat for CRB introduction and spread. In other species, it has been recorded that adult moths of the fall armyworm, Spodoptera frugiperda, can fly up-North from Mississippi in the Southern United States to Canada in around 30 hours aided by low-level jet-streams (Westbrook et al. 2016).

For CRB, laboratory experiments using flight mills have indicated that the beetles can fly up to 2 to $4 \mathrm{~km}$ in 2 to 3 hours (Hinckley 1973). However, when retested after a day or twos rest, the beetles never flew more than 30 minutes. How wind currents, jet-streams and extreme wind speeds such as those experienced during cyclones affect, CRB flying distance remains to be tested. Field observations point to more conservative figures in the range of 10-23 meters only per day 
(Kamarudin \& Washid 2004). But this is surely affected by factors such as the availability and relative abundance of food, breeding sites and the need for the beetles to fly long distances in search of these.

\section{Challenges for PICTs}

\section{Surveillance for CRB-G}

An active surveillance program to act as an early warning system for CRB-G incursion is non-existent in many PICTs. The incursion of CRB-G in Honiara, Solomons is estimated to have occurred more than a year before it was detected (Vaqalo et al. 2017). The presence of an early warning system in the Solomons would have led to the timely detection of CRB-G and subsequent implementation of containment and eradication measures. The delayed detection and subsequent response allow pests to become well established, which puts additional pressure on resources and reduces the chances of eradication (ISSG 2005).

\section{Identification and confirmation}

The identification and differentiation of CRB-G from CRB-P will be very challenging for countries which already have widespread CRB-P presence as both biotypes morphologically look the same. Distinguishing between the two haplotypes by genomic (nucleotide sequence) variability would require molecular techniques and bioinformatics assessment (Marshall et al. 2017). Most National Plant Protection Organizations (NPPO) in the PICTs lack tools for molecular identification (ID) thus would be heavily reliant on third-party diagnostics services which are usually performed in a foreign country. This may quickly become a costly exercise as every sample collected under suspicion of being the CRB-G strain would need to go through the same level of screening for ID confirmation. Secondly, this puts Pacific island nations at a disadvantage as the ID procedures may delay the response roll-out for a possible CRB-G incursion due to the fact that significant time would be consumed (and lost) in processes from sample collection and submission to receiving the diagnostics reports back and then making decisions to fight back against a positive CRB-G find.

\section{Preparedness of PICTs for an incursion}

Some regional NPPOs may still lack a biosecurity Emergency Response Plan (ERP) to deal with the incursion of high priority pests, or such documents are currently being drafted; in other cases, even a "high priority pest list" is not drawn up. The absence of an ERP document that has had its procedures trialled, tested and fine-tuned suggest that NPPOs may not be well prepared and have no guidance/action plan for investigation, detection and diagnosis of suspected TPPs let alone a high-level plan for containment and/or eradication of the TPP. Immediate as well as full implementation of an ERP is further subjected to the availability of the following:

- Financial resources - access to liquid or easily convertible emergency response fund

- Human resources - the ability to pool relevant personnel from within and outside the organization

- Surveillance resources - additional traps, lures, field kits, inspection kits, collection kits and survey items

- Laboratory resources - the ability to upscale diagnostics activities, handle high sample numbers and perform identification to species and strain level

Such resources, where not pre-planned and purchased, may need to go through discussions or grant processes of relevant Government Ministries or departments, even cabinet approval for additional funds and endorsement of the implementation of ERP. Any delay in response will allow the TPPs or IAS to establish further-this will off course add burden to containment and eradication efforts when launched. 


\section{Lack of expertise and funding}

Many-a-times, PICTs may lack experts for specific pests, diseases and/or weeds as well as diagnostics services and thorough understanding of the epidemiology of the pest outbreak. Thus during incursions, foreign experts may be identified and hired to assist. The hiring of experts or consultants is a lengthy affair; it may delay the response process and incur huge amounts of additional costs that many PICTs cannot afford. This was unfortunately faced in Vanuatu during the most recent CRB outbreak (Roberts 2019).

\section{Insect management}

Cultural control of CRB is difficult, firstly because adults bore and sustain themselves in palm trees several meters high, only to fly and lay eggs in organic matter or mulch piles (Vaqalo et al. 2017). This is possibly one of the many reasons why the beetles are so successful in establishing in new locations once introduced. NPPOs detecting CRB larvae or pupae would mean the response team needing to dig through and treat every organic trash or mulch pile in a designated area-an unprecedented and extremely cumbersome task, especially where infestations are widespread.

Biocontrol has historically proven to be a great success. OrNV, a baculovirus, originally discovered in Malaysia (Hiiger 1966) and subsequently found in Indonesia and the Philippines (Zelazny 1977) was first introduced in Samoa in the 1960s to control CRB-P (Marshall et al. 2017). This resulted in massive suppression of the CRB-P population-paving the way for the release of the virus in all countries with CRB-P during the 1960s and 1970s (Marschall 1970, Young \& Longworth 1981, Marschall \& Ioane 1982, Zelazny et al. 1992). Consequently, CRB-P invasion of new PICTs has not been seen for almost 40 years. However, CRB-G appears to be highly resistant to OrNV infection; PCR analysis indicates that the virus is generally not present in invasive CRB-G populations whereas greatly detectable in already established CRB-P populations (Marshall et al. 2017). This now brings new challenges as well as the window of opportunity for scientists to identify new bio-control agents against CRB-G that would assist in bringing the population down and curb its rapid spread across the PICTs.

\section{CRB-G prevention and control}

All regional NPPOs must firstly review their import requirements for coconut, copra and byproducts to ensure all measures are being taken pre-border to prevent the transfer of all stages of CRB in such commodities. This review should also be done domestically, ensuring CRB is not spread into islands that do not have an infestation. Where domestic quarantine procedures do not exist, these should be enacted and awareness created to assist in the implementation of requirements safeguarding uninfested areas and educating communities on the negative impacts of a CRB incursion.

NPPOs further need to establish surveillance for CRB. The early warning systems need to be strategically implemented with a focus on high-risk sites, human-aided movement and also for natural pathways. The lures used for CRB surveillance should be tested for effectiveness and longevity in the local environment as tropical weather may limit the efficiency of the lures for a prolonged period; traps, where installed, should also be well-maintained and serviced at regular intervals. Other technology for CRB surveillance apart from the lure system should also be considered where financial and physical resources allow. Innovative interventions that make detection more efficient such as the use of digitally collected and assessed sound waves for locating CRB and other sound-producing insects in live and dead trees including logs has been trialled successfully in Guam (Mankin \& Moore 2010).

It is wise for PICT governments to invest in mini-molecular labs and build staff capacity in this area, not just for CRB identification but for other TPPs as well. NPPOs should also identify experts locally, regionally and internationally who can assist if ever there is an incursion. Utmost priority, however, must be given to all activities related to prevention and preparation for an outbreak rather than passive and reactive action once CRB arrives. 


\section{Lethal Yellowing Disease (LYD) of Coconut}

Lethal yellowing is caused by phytoplasma in the 'coconut lethal yellowing group 16SrIV' (Harrison et al. 2002a, b) which are separated from other phytoplasmas by RFLP analysis of PCRamplified 16SrDNA sequences (Lee at al. 1993). While local names where this disease is found vary, the formal name Candidatus Phytoplasma palmae is commonly used. LYD was first recorded in the Caribbean in the late 1800s (Johnson 1912, Plavsic-Banjac et al. 1972). This was followed by the discovery of the disease in Florida, Jamaica, southern Mexico, Honduras (Ashburner et al. 1996), Haiti, Cuba, Belize and the Bahamas (McCoy et al. 1983, CABI 2019). The disease then spread Eastwards and was further recorded in countries such as Benin, Cameroon, Ghana (Danyo 2011), Kenya, Mozambique (Harrison et al. 2014), Nigeria (Osagie et al. 2015), Tanzania, Togo, India, Sri Lanka, Indonesia and more recently PNG (Kelly et al. 2011).

Chronologically mapping the gradual find of LYD in new locations establishes a plausible pattern for the movement of LYD from the Caribbean to the Americas, then eastwards to Africa and Asia and more recently to the Pacific (PNG). Here the disease is commonly called Bogia Coconut Syndrome (BGS) (Jackson 2017, Gurr et al. 2016). A separate study (Lu et al. 2016) suggests that BGS is caused by a phytoplasma distinct from the coconut lethal yellowing group. Whatever the case, it is surely a major worry for all PICTs that rely heavily on coconut for sustenance and income generation.

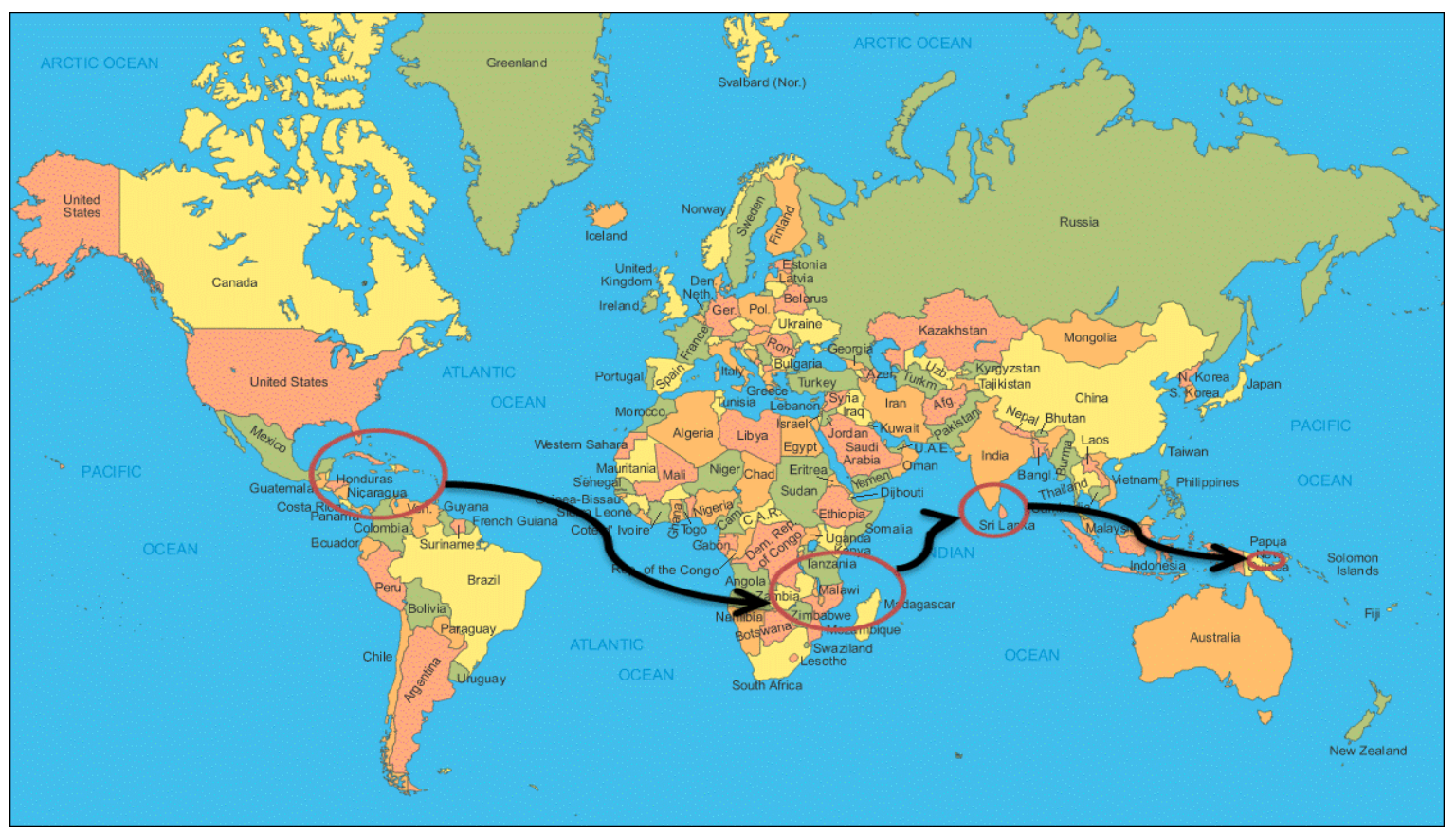

Fig. 3 - Illustration of LYD distribution and sneaky transmission into the Pacific

\section{Symptoms of LYD}

Flower necrosis, fruit drop and foliar discolouration are three key indicators of LYD. Importantly, not one single symptom alone fully identifies the disease, and rather it is the appearance and progression of symptoms over a period of time that more concretely helps identify LYD (Harrison et al. 1999, Eziashi \& Omamor 2010).

In infested coconut palms, emerging flower spikelets will appear partially or totally blackened instead of having the normal light yellow to creamy white colour. In trees capable of producing nuts, the fruits will drop prematurely, and the calyx or stem end of the nut will usually have a brown to the black, water-soaked appearance while the leaves will begin turning yellow to brown, older ones first followed by younger leaves moving up the crown. This is more common in tall varieties (Dollet et al. 2009, Bertaccini et al. 2014). 
Roca de Doyle (2001) through electron microscopy analysis of tissues from affected palms identified that the phloem vessels become packed with phytoplasma cells thereby causing physical obstruction to the flow of nutrients, which eventually results in the death of palm trees.

\section{Biosecurity threat from LYD}

Coconut continues to be one of the key sources of income for people of all PICTs, in addition to being utilized for food, feed and fuel. Thus any pest or disease that could lead to the death of palms and potentially cause an epidemic is of great concern. LYD has significantly impacted the coconut industry in countries where its occurrence has been noted. Eziashi \& Omamo 2010 with reference to Odewale et al. 2010 reported that in Nigeria, there is an estimated 13,615 hectares of land covered by more than 2 million coconut trees - providing a livelihood for over 30,000 rural families. LYD was first discovered in Nigeria in 1995, affecting at least 10 hectares. By the dry season of the $11^{\text {th }}$ year (2006), almost $99 \%$ of the West Africa Tall palms and $72 \%$ of Dwarfs were lost.

A study in Grand-Lahou, a coastal town in southern Ivory Coast (Mahyao et al. 2016) showed that devastation to coconut plantations affected family income and consequently increased food and non-food related expenses, especially on health care while chewing into school expenses thereby affecting education in many communities. Earlier, McCoy et al. 1983 had reported that in 30 years after the first infestation, an astonishing 4 million of Jamaica's five million coconut palms and close to half of Florida's one million coconut palms were lost to LYD. Therefore, it is crucial that all PICTs free of LYD implement precautionary measures to prevent the incursion of this apocalyptic and economically devastating disease.

\section{Pathways for LYD introduction}

LYD is a vector-transmitted disease spread by piercing and sucking insects which carry the phloem-limited phytoplasma from palm to palm as they move along during their feeding cycles (Broschat et al. 2002, Harrison et al. 2004). Cordova et al. 2003 reported that the vector in Southern Florida, USA is the planthopper Myndus crudus Van Duzee. The group also reported that phytoplasma DNA could be detected in coconut embryos. Pilotti et al. 2014 identified Zophiuma pupillata [Lophopidae] and Proustia sp. [Derbidae] as vectors of LYD in PNG. This means that the risk of spread for LYD is two-pronged; it is possible via infected coconut material as well as through vectors. In view of these findings, the possible pathways for the spread of LYD include:

I. Movement of infected planting material, especially coconut fruits.

II. Trade-in host materials of the vectors that may lead to the transfer of infected vector insects. For example, grasses and palm trees imported into Mexico from Florida for new golf courses may have harboured vector species and could have led to LYD first appearing in Mexico in the 1980s later spreading to Central America (Dollet et al. 2009).

III. Natural phenomenon such as the swarming of vectors and movement into newer locations. Insects can travel, by a single flight, over distances ranging from a few meters to more than 3,000 kilometres and this is illustrated by back-tracks of wind trajectories associated with the arrival of immigrant insects into Britain from Scandinavia, possibly east Russia, Germany, Morocco, the Azores, Spain and the U.S.A (Johnson 1967). In the Caribbean, the spread of vector insects to new areas has resulted in LYD outbreaks suggesting a non-native origin of the disease (Brown et al. 2006, Elliott 2009).

\section{Challenges for PICTs}

\section{Detection of LYD}

Phytoplasma responsible for LYD can only be diagnosed using molecular techniques where DNA extraction, PCR amplification (Harrison et al. 2002b, Gurr et al. 2016), sequencing and bioinformatics software for sequence assembly, sequence analysis and barcoding work is required (Makarova et al. 2012, Paltrinieri et al. 2015). Most PICTs, while working towards capacity and 
capability development, still lack the facilities and equipment to conduct molecular diagnostics. This is further compounded by the lack of overseas collaborative laboratories or "twinning partners" to provide such services at low or zero cost. Additionally, countries that do have necessary molecular equipment may lack sequencing capability to complete a diagnosis.

\section{Detection and confirmation of vectors}

Various insects are associated with LYD transmission in different countries, and in most cases, the vectors are not yet identified. For instance, the LYD vector in Florida, Haplaxius crudus ex-Myndus (Howard et al. 1983) does not exist in Africa. In addition, H. crudus has never been recorded in Haiti or the Dominican Republic so far. Another insect of the same family (Cixiidae), Myndus adiopodoumeensis was long suspected of being the vector for the Cape St Paul wilt (CSPW) disease of coconut, the local name for LYD, in Ghana (Philippe 2007). That species does not exist in Tanzania. Hence, more or less dependent on geographic location, reservoirs of vectors and inoculum, be it on native palms or any other plant, will probably be different. Additionally, where insects are identified to carry the phytoplasma of concern via PCR analysis (Eckstein et al. 2014), they can only be known as putative vectors (Pilotti et al. 2014) because it is experimentally and logistically difficult to conduct transmission studies on coconut palms and prove true transmission as would happen in nature (Gurr et al. 2016).

\section{Multiple hosts and surveillance for LYD}

The phytoplasma causing LYD in coconut palms has multiple hosts (Table 2) within the Arecaceae family; thus, it is essential that individual PICTs identify the distribution of alternative hosts in their countries. If ever an incursion occurs, it may not necessarily be the case where the coconut palm is the primary host. It is prudent that any surveillance program for LYD focuses on the primary as well as all alternative hosts to establish timely detection and roll out appropriate response for an incursion.

Table 2 List of palm species in PICTs known to be susceptible to LYD (16SrIV-A) (Harrison et al. 1999, Howard 2001)

\begin{tabular}{lll}
\hline \multicolumn{1}{c}{ Scientific name } & \multicolumn{1}{c}{ Common name } & \multicolumn{1}{c}{ Origin } \\
\hline Cocos nucifera & Coconut palm & Western Pacific \\
Cyphophoenix nucele & Lifou Palm & New Caledonia \\
Howea belmoreana & Belmore sentry palm & Western Pacific \\
Howea forsteriana & Kentia or Sentry palm & Western Pacific \\
Pritchardia pacifica & Fiji island fan palm & Western Pacific \\
Prichardia remota & - & Hawaiian Islands \\
Pritchardia thurstonii & Thurston palm & Western Pacific \\
Veitchia arecina & Majesty Palm & Fiji, Vanuatu, Tonga \\
Veitchia merillii & Christmas palm & Western Pacific \\
Veitchia mcdanielsi & Sunshine palm & Western Pacific \\
Veitchia montgomeryana & Montgomery’s palm & Western Pacific \\
\hline
\end{tabular}

\section{LYD prevention, control and management}

\section{Pre-border quarantine measures}

a. If importing coconut or other types of palm for propagation or rehabilitation programs, PICTs should implement import conditions such as the requirement for disease freedom and PCR testing for LYD absence. This will ensure only LYD free planting material is being transferred.

b. Measures should also be implemented to prevent the introduction of exotic vector-insects capable of carrying the phytoplasma-including vigilant border inspections for products from countries known to have the disease. 
c. It is recommended that PICTs strengthen their pest and disease database to establish a local species list for ease of comparison against exotic ones. This will assist in decision making for confirmation of exotic or regulatory status as well as incursion and response strategies.

\section{Domestic Quarantine}

a. Surveillance

PICTs should ideally undertake active aerial surveillance of coconut and other types of palm plantations for timely detection of an incursion. Depending on their distance from commercial centres such as a port of entry or hotel clusters, the plantations or natural clusters can also be demarcated as high, medium and low at risk whereby surveillance activities can be strategically designed for each zone and undertaken accordingly making efficient use of available NPPO resources.

It is common knowledge that the window of opportunity for the eradication of any pest or disease highly depends on timely detection of the pest or pathogen of concern. Therefore, random sample collection and molecular disease testing are also encouraged, the protocols for which are described in Harrison et al. (1999), Harrison et al. (2002b), Gurr et al. (2016), Rosete et al. (2016).

b. Phytosanitation

Most palm plantations in the PICTs are not managed through commercial agronomic practices. Poor sanitation beneath the palm canopy will provide conducive breeding sites for pests including LYD vectors, thereby increasing the risk of disease infestation and quick spread after an incursion. Good field sanitation will reduce or eliminate this risk.

c. Destruction of diseased plants

Where LYD infestation is confirmed, all efforts should be made to destroy such plants to prevent further spread of the disease. Delayed rouging and destruction of diseased palms will allow vectors to pick up and transmit the phytoplasma further, even causing sporadic (jump) infestations (Harrison \& Elliot 2008) that is sure to impede eradication efforts.

d. Detection of vectors

All PICTs apart from PNG are currently free of LYD (the pathogen) and should maintain a list of vectors already present in each country, if any, and make efforts to conduct surveillance and test them regularly. Should there ever be a case where suspected entry of LYD vector insect is reported, it is essential that the specimen is identified in the shortest timeframe possible so that the most feasible and effective measures could be implemented in the eradication and control of the insect using insecticides, mass trapping and bio-control agents where needed.

\section{Resistance and cropping patterns}

a. Resistant or tolerant varieties

No coconut cultivar has so far been identified to be completely resistant to LYD (Baudouin et al. 2009). Hundreds of coconut varieties are grown within the PICTs, and it is important that such heterogeneity is maintained. PICTs should work together to identify LYD resistant and tolerant varieties and promote their cultivation for recovery programs should there ever be an LYD incursion. A generic problem associated with such a selection and/or breeding program is that cultivars identified as resistant to the phytoplasma may still be susceptible to attack by other pests or diseases or have undesirable economic or cosmetic traits constraining their value and adoption (Gurr et al. 
2016). This, however, does not dampen the fact that finding LYD resistant or tolerant coconut varieties should be a top-most priority.

\section{b. Intercropping}

Planting suitable crops in plantation in-between palm trees is considered an advantage when dealing with LYD. For example, in the Caribbean, a Jamaican farmer by the name Michael Black pioneered the integrated pest and disease management (IPDM) method which proved to be the most successful in reducing the incidence of LYD (Serju 2012, CARDI 2013). This method, called Black's approach involves on-farm quarantine, strict weekly surveillance, cutting down and burning of palms with LYD symptoms and replanting with a variety selected for high yield and LYD resistance. This is combined with whole-farm weed control and a good fertilization regime (Myrie et al. 2011, CARDI 2013).

\section{Cadang-cadang}

The Coconut cadang-cadang viroid (CCCVd), is the causal organism of the "cadang-cadang disease" (CCD) in coconut, initially reported on San Miguel Island in the Philippines in 1927/1928 (Hanold \& Randles 1991). The disease resulted in total losses of about 30 million palms and annual yield losses of about 22,000 tons of Philippines copra (Zelazny 1980). This subsequently heavily affected the production of copra, coconut oil and other by-products. CCCVd-like infection has also been recorded in the Solomon Islands (Randles et al. 1991) whereas the related Coconut tinangaja viroid (CTiVd) has been identified in Guam causing similar problems; here it is called the "tinangaja disease" (Boccardo et al. 1981). Viroids with similar nucleic acid sequences as that of CCCVd are found in Asia and the South Pacific. While sharing a high degree of sequence homology, their pathogenicity remains relatively unknown (Hanold \& Randles 1991).

\section{Symptoms}

Zelazny et al. (1982), Hanold \& Randles (1991) have described the symptoms of the cadangcadang disease in three stages as below.

Early-stage (lasting 2-4 years): yellow leaf spots appearing water-soaked in reflected light and translucent yellow in transmitted light. Nuts become small and rounded, with characteristic equatorial scarifications.

Medium stage (lasting around two years): leaf spots become numerous, giving the lower twothirds of the crown a yellowish appearance. Inflorescences become necrotic, infertile and nut production ceases. Frond production and size also decline.

Late-stage (lasting around five years): leaf spots are almost confluent. The whole crown becomes yellow/bronze-coloured and much reduced in size and number of fronds. Leaflets become brittle, and palm dies. Time from the appearance of first symptoms to tree death ranges from around 8 to 16 years and is generally more significant in older palms.

\section{Biosecurity threat from CCD}

Cadang-cadang is a disease of concern for PICTs as much like CRB-G and LYD, CCD will also affect the livelihoods of a large proportion of the Pacific population dependent on coconut palms surviving many years and producing a high number of nuts. The subtle symptoms of the disease are recognized by trained eyes, and this makes timely detection of plants infected with the CCCVd very challenging. In other words, countries risk having the disease and completely not know of its existence.

CCCVd infection is usually observed after palms reach ten years of age and the incidence then increases linearly for up to 40 years and remains constant for older palms (Zelazny \& Niven 1980, Zelazny \& Pacumbaba 1982). Within this period, other plants in close proximity of the infected plant may also become diseased yet show no symptoms. The lack of a specific pattern of disease increase does not allow the source of infection in a plantation to be determined, and there 
are still many questions to be answered before its epidemiology is sufficiently understood for control measures to be developed (Zelazny \& Niven 1980, Randles et al. 1992).

More so, no vectors have been identified which are responsible for spreading the disease and whether the viroid is mechanically transmissible is also unknown. However, transmission through pollen and seed can occur. Pacumbaba et al. 1992 found that progenies of healthy palms pollinated with infected pollen exhibited disease symptoms six years after germination. No field control measures exist for CCCVd. More studies on the epidemiology of the viroid and aetiology of the disease are required for the development of specific control measures which would include the elimination of reservoir species, vector control, mild strain protection and breeding for host resistance (Randles at el. 1988).

\section{Challenges for PICTs}

\section{Detection and local movement}

Fresh or dried nuts and germplasm (germinating nuts) are some of the most exchanged commodities at the community level in PICTs. If the disease was to arrive in the islands basin, there are high possibilities that CCD would be distributed widely even before its detection. Secondly, CCD diagnosis is complex and demands laboratory facilities capable of serological and molecular work for identification which is lacking in the majority of the PICTs.

\section{Monitoring and surveillance}

It could be well up to three years after infection for the CCD symptoms to become visible. Even then, it takes a keen eye to notice these symptoms and raise the alarm. This complicates NPPO efforts to actively monitor for CCD in plantations and high-risk areas or conduct surveillance for the disease in wild clusters. Farmers may also not be able to recognize symptoms and report anomalies in palm growth due to the lack of knowledge about this disease and awareness.

\section{Pathways for CCD introduction}

The import of coconut seedlings and nuts, including infested tissue cultures from risk countries can spread this viroid into new locations (Pacumbaba et al. 1992). Such import usually occurs for breeding programs and rehabilitation or recovery after natural disasters.

\section{CCD prevention and control}

Because of the little known distribution of CCD, the importation of palm seedlings or propagating material, including embryo (tissue) cultures, even from countries with no records of CCCVd infestation should take place under stringent biosecurity screening or not take place at all. Because no insect vector is known, it is recommended for NPPOs to proactively closely monitor for coconut pests in all consignments from the risk area and conduct random tests on intercepted specimens for CCD.

\section{Strengthening domestic biosecurity}

While NPPOs focus on manning international borders, the absence or weak enforcement of domestic biosecurity laws in outer, mostly remote islands may also potentially lead to the introduction of TPPs. Domestic quarantine for inter-islands can be re-enforced through:

- Timely, regular and tailor-made awareness programs for these communities

- Identification of influential personnel or positions in these areas who could advocate on biosecurity issues and encourage community members to report plant health issues

- Installation of appropriate surveillance and early warning systems including regular servicing and maintenance of such systems 
- Providing basic biosecurity trainings to identified locals who can perform duties such as laying and maintenance of traps; collection of trap specimen and submission to the diagnostic labs; understanding pest and disease signs and symptoms and promptly reporting for further investigation

- Conducting planned targeted pests survey activities at least once a year and mandatorily after every natural disaster

\section{Conclusion}

Agricultural pests are always on the move and by-passing borders either through natural migration or human aided activities. The coconut TPPs described in this paper can have dire consequences for all PICTs, which need to be proactive in their biosecurity approach towards these pests. Regional NPPOs must implement measures that deter the introduction or quickly detect possible incursions at the earliest so that eradication and control measures can be implemented without any delay. If identified early, incursions are usually noted on one or a very few islands; here, management measures can be implemented rapidly and spread of the pest to other islands curbed quickly. Geographic isolation and islands scattered in the vast Pacific Ocean are in fact advantageous to the PICTs because quarantine pests can be contained, controlled or eradicated in small areas through the application of appropriate procedures.

Timing is key if incursion of an unwanted pest occurs. The "window of opportunity" for eradication is minimal, and any delay will lead to the establishment of the pest. There is a need to increase vigilance on high-risk pathways and prioritize surveillance in high-risk areas; natural pathways should also form part of the national surveillance system. Emergency response plans should be trialled and working effectively; all stakeholders, relevant government and nongovernment agencies should stand ready to assist during incursions and outbreaks. Moreover, biosecurity awareness must be prioritized by all regional NPPOs-farmers, agricultural officers and people at large cannot report what they do not know about. The public should be aware of the dreadful threats that loom beyond the horizons and how, as individuals and communities, they can assist in preventing introductions and assist in early detection.

\section{Acknowledgements}

We thank Mr. Livai Nakuta, GIS Officer of the Biosecurity Authority of Fiji (BAF) for plotting the CRB distribution within PICs map.

No financial obligations are attached to this work.

\section{References}

Ahuja SC, Ahuja S, Ahuja U. 2014 - Coconut-History, uses and folklore. Asian Agri-History Vol. 18, No. 3, 221-248.

Ali M. 2018 - Role of Post-tensioned Coconut-fibre Ropes in Mortar-free Interlocking Concrete Construction during Seismic Loadings. KSCE Journal of Civil Engineering 22, 1336-1343.

Anon. 2017 - Action Plan for Oryctes rhinoceros 2018-2023. Department of Lands and Natural Resources, Commonwealth of the Northern Mariana Islands (CNMI). Saipan, Northern Mariana Islands https://opd.gov.mp/wp-content/uploads/opd/CNMI-Rhino-Beetle-Plan.pdf (Accessed 14 February 2020)

Ashburner G, Cardova I, Oropeza C, Illingworth R et al. 1996 - First report of coconut lethal yellowing disease in Honduras. Plant Disease. 80, 960.

Atoyebi AD, Osuolale OM, Ibitogbe EM. 2019 - Strength Evaluation of Cocos nucifera Fibre Reinforced Concrete. Journal of Engineering and Applied Sciences 14 (21), 8061-8066.

Barney P. Caton BP, Dobbs TT, Brodel CF. 2006 - Arrivals of hitchhiking insect pests on international cargo aircraft at Miami International Airport. Biological Invasions. 8, 765-785. 
Bedford GO. 1974 - Descriptions of the larvae of some rhinoceros beetles (Col., Scarabaeidae, Dynastinae) associated with coconut palms in New Guinea. Bulletin of Entomological Research, 63(3), 445-472.

Bedford GO. 1980 - Biology, ecology, and control of palm rhinoceros beetles. Ann. Rev. Entomol. 25, 309-339

Belayachi M, Hoxha D, Ismail B. 2017 - Impact of fiber treatment on the fire reaction and thermal degradation of building insulation straw composite. Energy Procedia 139, 544-549.

Bertaccini A, Duduk B, Paltrinieri S, Contaldo N. 2014 - Phytoplasmas and phytoplasma diseases: a severe threat to agriculture. Am. J. PlantSci. 5, 1763-1788.

Boccardo G, Beaver RG, Randles JW, Imperial JS. 1981 - Tinangaja and bristle top, coconut diseases of uncertain etiology in Guam and their relationship to cadang-cadang disease of coconut in Philippines. Phytopathology 71(10), 1104-1107.

Broschat TK, Harrison NA, Donselman H. 2002 - Losses to lethal yellowing cast doubt on coconut cultivar resistance. Palms 46, 185-189.

Burgiel S, Muir A. 2010 - Invasive Species, Climate Change and Ecosystem-Based Adaptation: Addressing Multiple Drivers of Global Change Global Invasive Species Programme.

CABI. 2019 - Candidatus Phytoplasma palmae (lethal yellowing of coconut) [reviewed by Harrison NA]. In: Invasive Species Compendium. Wallingford, UK: CAB International. http://www.cabi.org/isc/datasheet/38647 (Accessed 8 May 2019)

Campbell-Falck D, Thomas T, Falck TM, Tutuo N et al. 2000 - The intravenous use of coconut water. American Journal of Emergency Medicine 18, 108-111.

CARDI. 2013 - Coconut Industry Development for the Caribbean: Towards a Shared Vision and Road Map, George town Guyana: CARDI.

Catley A. 1969 - The coconut rhinoceros beetle Oryctes rhinoceros (L.) (Coleoptera: Scarabaeidae: Dynastinae). Pest Articles and News Summaries 15, 18-30.

CBD. $1992-$ (Convention on Biological Diversity) Glossary of terms. https://www.cbd.int/invasive/terms.shtml (Accessed 8 May 2019).

Cordova I, Jones P, Harrison NA, Oropeza C. 2003 - In-situ PCR detection of phytoplasma DNA in embryos from coconut palms with lethal yellowing disease. Molecular Plant Pathology 4, 99-108.

Danyo G. 2011 - Review of scientific research into the Cape Saint Paul Wilt Disease (CSPWD) of coconut in Ghana. Afr. J. Agric. Res. 6, 4567-4578.

DAWE. 2017 - (Department of Agriculture, Water and the Environment) Revised import conditions for fresh coconuts and coconut meat 105-2017. https://www.agriculture.gov.au/import/industry-advice/2017/105-2017 (Accessed 15 June 2019)

DebMandal M, Mandal S. 2011 - Coconut (Cocos nucifera L.: Arecaceae): In health promotion and disease prevention. Asian Pacific Journal of Tropical Medicine 4(3), 241-247.

Dollet M, Quaicoe R, Pilet F. 2009 - Review of Coconut "Lethal Yellowing” type diseases. Diversity, variability and diagnosis. Oilseeds and fats, Crops and Lipids 16, 97-101.

Eziashi E, Omamor I. 2010 - Lethal yellowing disease of the coconut palms (Cocos nucifera 1.): An overview of the crises. African Journal of Biotechnology 9(54), 9122-9127

FAO. 2001 - (Food and Agriculture Organization) Part III: Economic Impacts of Transboundary Plant Pests and Animals Diseases. In: The State of Food and Agriculture 2001. Rome, Italy. http://www.fao.org/3/x9800e/x9800e00.htm\#TopOfPage (Accessed 8 May 2019).

FAO. 2019 - (Food and Agriculture Organization) Glossary of phytosanitary terms. International Standard for Phytosanitary Measures No. 5. Rome. Published by FAO on behalf of the Secretariat of the International Plant Protection Convention (IPPC).

FAO. 2020 - (Food and Agriculture Organization) Plant pests and diseases in: FAO in emergencies. 
http://www.fao.org/emergencies/emergency-types/plant-pests-anddiseases/en/?page=1\&ipp=10\&tx_dynalist_pi1[par]=YToxOntzOjE6IkwiO3M6MToiMCI7f Q (Accessed 23 May 2020).

Foale M. 2003 - The coconut odyssey: the bounteous possibilities of the tree of life. ACIAR Monograph No. 101.

Freeman A, Rodoni B, Taufatofua D, Taufa L et al. 2010 - Impact of Climate Change on Food Security and Biosecurity of Crop Production Systems in Small Pacific Nations. Asia-Pacific Network for Global Change Research project report: ARCP2010-08NSY-Freeman. https://www.apn-gcr.org/resources/files/original/6ab2c34a 8edf4dd6fec3ed54a317c1c2.pdf (Accessed 23 May 2020).

Global Invasive Species Database. 2019 - Species profile: Oryctes rhinoceros. http://www.iucngisd.org/gisd/species.php?sc=173 (Accessed 9 May 2019).

Goonewardene P. 1958 - The rhinoceros beetle (Oryctes rhinoceros L.) in Ceylon. Part 1. Introduction, distribution and life history. Tropical Agriculture 114, 39-60.

Gressitt JL. 1953 - The coconut rhinoceros beetle (Oryctes rhinoceros), with particular reference to the Palau Islands. Bernice P. Bishop Museum Bulletin 212, 1-157.

Gurr GM, Johnson AC, Ash GJ, Wilson BAL et al. 2016 - Coconut Lethal Yellowing Diseases: A Phytoplasma Threat to Palms of Global Economic and Social Significance. Frontiers in Plant Science 7, 1521. Doi: 10.3389/fpls.2016.01521.

Handreck KA. 1993 - Properties of coir dust, and its use in the formulation of soilless potting media. Communication in Soil Science and Plant Analysis 24,349-363.

Hanold D, Randles JW. 1991 - Coconut Cadang-Cadang Disease and Its Viroid Agent. Plant Disease 75, No. 4. The American Phytopathological Society.

Harrison NA, Davis RE, Oropeza C, Helmick EE et al. 2014 - 'Candidatus Phytoplasma palmicola', associated with a lethal yellowing-type disease of coconut (Cocos nucifera L.) in Mozambique. Intern. J. Syst. Evolut. Microbiol. 64, 1890-1899.

Harrison NA, Elliott ML. 2008 - Lethal Yellowing of Palms. The Plant Health Instructor. Doi: 10.1094/PHI-I-2008-0714-01

Harrison NA, Myrie W, Jones P, Carpio ML et al. 2002a - 16Sr RNA interoperon sequence heterogeneity distinguishes strain populations of palm lethal yellowing phytoplasma in the Caribbean region. Annual Applied Biology 141, 183-193.

Harrison NA, Womack M, Carpio ML. 2002b - Detection and characterization of a lethal yellowing (16SrIV) group phytoplasma in Canary Island date palms affected by lethal decline in Texas. Plant Disease 86(6), 676-681.

Harrison, NA, Cordova I, Richardson P, DiBonito R. 1999 - Detection and diagnosis of lethal yellowing. Pages 183-196 in: Oropeza C, Verdeil JL, Ashburner GR, Cardeña R, Santamaría $\mathrm{JM}$, eds. Current Advances in Coconut Biotechnology. Current Plant Science and Biotechnology in Agriculture, vol 35. Springer, Dordrecht, Netherlands.

HISC. 2015 - (Hawaii Invasive Species Council) Coconut Rhinoceros Beetle (Oryctes rhinoceros). https://dlnr.hawaii.gov/hisc/info/invasive-species-profiles/coconut-rhinoceros-beetle/ (Accessed 14 February 2020)

Hinckley AD. 1973 - Ecology of the coconut rhinoceros beetle, Oryctes rhinoceros (Coleoptera: Dynastidae). Biotropica 5 (2), 111-116.

Hiiger AM. 1966 - A virus disease of the Indian rhinoceros beetle Oryctes rhinoceros (Linnaeus) caused by a new type of insect virus, Rhabdionvirus oryctes gen. n., sp. n. Journal of Invertebrate Pathology 8 (1), 38-51.

Howard FW, Norris RC, Thomas DL. 1983 - Evidence of transmission of palm lethal yellowing agent by a planthopper, Myndus crudus (Homoptera: Cixiidae). Tropical Agriculture 60, 16871.

Howard FW. 2001 - "Sap-feeders on Palms," in Insects on Palms, eds F.W. Howard D, Moore RM, Giblin-Davis, Abad RG. Wallingford, CT: CABI Publishing, 109-232.

Hume EP. 1949 - Coir dust or cocopeat-a by-product of the coconut. Economic Botany 3, 42-45. 
IPPC. 2007 - (International Plant Protection Convention) International Standards for Phytosanitary Measures (ISPM) 5 - Glossary of Phytosaniatry Terms. Rome. Published by FAO on behalf of the Secretariat of the International Plant Protection Convention.

https://www.ippc.int/en/publications/622/ (Accessed 8 May 2019).

ISSG. 2005 - (Invasive Species Speacilist Group) Introduction to Invasive Alien Species Module 1.

http://www.issg.org/pdf/publications/GISP/GISP_TrainingCourseMaterials/Management/Ma naginginvasivesModule1.pdf (Accessed 15 May 2019)

Jackson G. 2017 - Coconut Bogia disease (229). In: Pacific Pests and Pathogens-Fact Sheets http://www.pestnet.org/fact_sheets/coconut_bogia_disease_229.htm (Accessed 25 May 2019)

Jackson AT, Marshall SDG. 2017 - Managing the threat of CRB-G, a new variant of the coconut rhinoceros beetle, in the Asia-Pacific Region. Proceedings of the PIPOC 2017 International Palm Oil Congress 1, 25-30, Kuala Lumpur, Malaysia.

Jarošík V, Kenis M, Honěk A, Skuhrovec J et al. 2015 - Invasive Insects Differ from Non-Invasive in Their Thermal Requirements. PLOS One. Doi: 10.1371/journal.pone.0131072.

Johnson JR. 1912 - The History and Cause of Coconut Bud-Rot. Washington, USA. USDA Bureau of Plant Industry Bulletin 228.

Johnson CG. 1967 - International dispersal of insects and insect-borne viruses. Journal of Plant Pathology 73, 21-43.

Kamarudin N, Washid MB. 2004 - Immigration and activity of Oryctes rhinoceros within a small oil palm replanting area. Journal of Oil Palm Research 16 (2), 64-77.

Kelly PL, Reeder R, Kokoa P, Arocha Y et al. 2011 - First report of a phytoplasma identified in coconut palms (Cocos nucifera) with lethal yellowing-like symptoms in Papua New Guinea. New Dis. Rep. 23, 9.

Kumar R, Haq MIU, Raina A, Anand A. 2018 - Industrial applications of natural fibre-reinforced polymer composites-challenges and opportunities. International Journal of Sustainable Engineering.

Lee IM, Hammond RW, Davis RE, Gundersen DE. 1993 - Universal amplification and analysis of pathogen 16S rDNA for classification and identification of mycoplasmalike organisms. Phytopathology 83(8), 834-842.

Lever RJAW. 1979 - Pests of the Coconut Palm. Food and Agriculture Organization of the United Nations, Rome. Plant Production and Protection Series No. 18, 190.

Liebhold AM, Work TT, McCullough DG, Cavey JF. 2006 - Airline Baggage as a Pathway for Alien Insect Species Invading the United States. American Entomologist Spring 48-54.

Lima EB, Sousa CN, Meneses LN, Ximenes NC et al. 2015 - Cocos nucifera (L.) (Arecaceae): A phytochemical and pharmacological review. Brazilian Journal of Medical and Biological Research 48(11), 953-964.

Madison D. 2017 - The Illustrated Encyclopedia of Fruits, Vegetables, and Herbs: History, Botany, Cuisine. New York, USA: Quarto Publishing.

Mahyao A, Ismael M, Konan JLK, Ibo JG et al. 2016 - Socio-economic impact of the coconut lethal yellowing disease on Ivorian smallholder coconut farm families. African Journal of Agricultural Economics and Rural Development 4, 463-479.

Mankin RW, Moore A. 2010 - Acoustic Detection of Oryctes rhinoceros (Coleoptera: Scarabaeidae: Dynastinae) and Nasutitermes luzonicus (Isoptera: Termitidae) in Palm Trees in Urban Guam. Journal of Economic Entomology 103(4), 1135-43. Doi: 10.1603/EC09214

Marschall KJ, Ioane I. 1982 - The effect of re-release of Oryctes rhinoceros baculovirus in the biological control of rhinoceros beetles in Western Samoa. Journal of Invertebrate Pathology 39(3), 267-276.

Marschall KJ. 1970 - Introduction of a new virus disease of the coconut rhinoceros beetle in Western Samoa. Nature 225, 288-289. 
Marshall SDG, Moore A, Vaqalo M, Noble A et al. 2017 - A new haplotype of the coconut rhinoceros beetle, Oryctes rhinoceros, has escaped biological control by Oryctes rhinoceros nudivirus and is invading Pacific Islands. Journal of Invertebrate Pathology 149, 127-134.

Marshall SDG, Moore A, Vaqalo M. 2016 - A New Coconut Rhinoceros Beetle Biotype Threatens Coconut and Oil Palms in Southeast Asia and the Pacific. https://cnas-re.uog.edu/wpcontent/uploads/2015/09/coconut-rhinoceros-beetle.pdf (Accessed 14 February 2020)

Mccoy RE, Howard FW, Tsai JH, Donselman HM et al. 1983 - Lethal yellowing of palms. University of Florida Agricultural Experiment Station Bulletin No. 834.

Nanda Kumar TB. 1990 - Tender coconut water: nature’s finest drink. Indian Coconut Journal 21, 14-18.

Nishida GM, Evenhuis NL. 2000 - Arthropod pests of conservation significance in the Pacific: a preliminary assessment of selected groups. Pp. 115-142 In: Invasive species in the Pacific: a technical review and regional strategy. (ed. G. Sherley). South Pacific Regional Environment Programme: pp. 190. Apia.

Odewale JO, Odionwaya G, Osagie JI, Ahanon JM. 2010 - Rate of lethal yellowing disease (LYD) spread in coconut (Cocos nucifera L.) plantation of tall interplanted Dwarf Varieties. 19 conference of Botanical Society of Nigeria: pp. 47. Katsina, Nigeria.

Osagie IJ, Ojomo EE, Pilet F. 2015 - Occurrence of Awka wilt disease of coconut in Nigeria for one century. Phytopathogenic Mollicutes 5, S61.

PHAMA Plus. 2019 - (Pacific Horticultural and Agricultural Market Access Plus Program) Coconut Sector Review: Review of PHAMA Plus's Strategy for Engagement with the Coconut Sector in the Pacific Islands.

http://phama.com.au/wp-content/uploads/2019/10/Coconut_Sector_Review_13Mar19-V1.0FINAL.pdf (Accessed 23 May 2020).

Pacumbaba EB, Zelazny B, Orense JC. 1992 - Pollen and seed transmission of the coconut cadangcadang viroid. Philippine Coconut Authority, Banao, Guinobatan, Albay (Philippines). Albay Research Center.

Philippe R, Nkansah JP, Fabre S, Quaicoe R. 2007 - Search for the vector of Cape Saint Paul Wilt (coconut lethal yellowing) in Ghana. Bulletin of Insectology 60, 179-80.

Pilotti CA, Dewhurst CF, Liefting LW, Kuniata L et al. 2014 - Putative vectors of a phytoplasma associated with coconut (Cocos nucifera) in Madang Province, Papua New Guinea. International Journal of Agriculture and Forestry 4, 365-372.

Plavsic-Banjac B, Hunt P, Maramorosch K. 1972 - Mycoplasma like bodies associated with lethal yellowing disease of coconut palms. Phytopathology 62, 298-299.

Prades A, Dornier M, Diop N, Pain J. 2012 - Coconut water uses, composition and properties: A review. Fruits 67(2), 87-107.

Raghavan K. 2010 - Biofuels from Coconut. FACT. https://energypedia.info/images/f/f9/ENBiofuels_from_Coconuts-Krishna_Raghavan.pdf (Accessed 23 May 2020).

Randles JW, Hanold D, Pacumba EP, Rodriguez MJB. 1991 - Cadang-cadang disease of coconut palm. In: Plant Diseases of International Importance. Mukhopadhyay AN, Kumar J, Chabue HS, Singh US, eds. Pretice Hall, Englewood Cliffs, NJ. In press.

Randles JW, Rodriguez MJB, Imperial JS. 1988 - Cadang-cadang disease of coconut palm. Microbiological Sciences, 5(1):18-22.

Roberts A. 2019 - Lack of manpower and funding to eradicate Coconut Rhinocerous Beetle. Vanuatu Daily Post. https://dailypost.vu/news/lack-of-manpower-and-funding-to-eradicatecoconut-rhinoceros-beetle/article_cd63a103-27f7-5e56-94f7-7838651d0d48.html

(Accessed 14 February 2020)

Roca de Doyle MN. 2001 - Crises research: Managing lethal yellowing disease. Biotechnology and Development Monitor 44/45, 12-15.

Rosete Y, Diallo H, Konan JL, Assiri PK et al. 2016 - Detection and identification of the coconut lethal yellowing phytoplasma in weeds growing in coconut farms in Côte d'Ivoire. Canadian Journal of Plant Pathology 38. DOI: 10.1080/07060661.2016.1191044 
SPC. 2017 - (Pacific Community) A new biotype of Coconut Rhinoceros Beetle discovered in the Pacific. Pest Alert No. 52 https://www.spc.int/sites/default/files/wordpresscontent/wpcontent/uploads/2017/08/Pest-Alert-52-Coconut-Rhino-Beetle2016-spc-lrd.pdf (Accessed 14 May 2019).

Sangamithra A, Swamy GJ, Sorna PR, Chadrasekar V et al. 2013 - Coconut: An extensive review on value added products. Indian Food Industry Mag 32(6), 29-36.

Smith C. 1995 - Coir: a viable alternative to peat for potting. The Horticulturist 4(3), 12, 25-28.

Tobin C. 2018 - Managing invasive species [version 1; peer review: 2 approved]. F1000Research 7(F1000 Faculty Rev): 1686.

Tsatsia F, Wratten H, Gharuka M, Fanai C et al. 2018 - The status of Coconut Rhinoceros Beetle, Oryctes rhinoceros (L) Scarabaeidae: Dynastinae, in Solomon Islands. https://devpolicy.org/pdf/blog/Status-of-the-coconut-rhinoceros-beetle.pdf (Accessed 14 February 2020)

Vaqalo M, Timote V, Baiculacula S, Suda G et al. 2017 - The Coconut Rhinocerous Beetle in Solomon Islands-A Rapid Damage Assessment of Coconut Palms on Guadalcanal. Pacific Community, Suva.

Waterhouse DF, Norris KR. 1987 - Biological Control Pacific Prospects. Australian Centre for International Agricultural Research. Inkata Press Pty. Ltd., Melbourne. pp. 454.

Westbrook JK, Nagoshi RN, Meagher RL, Fleischer SJ et al. 2016 - Modeling seasonal migration of fall armyworm moths. International Journal of Biometeorology 60(2), 255-267.

Young EC, Longworth JF. 1981 - The epizootiology of the baculovirus of the coconut palm rhinoceros beetle (Oryctes rhinoceros) in Tonga. Journal of Invertebrate Pathology 38(3), 362-369.

Zelazny B. 1977 - Occurrence of the baculovirus disease of the coconut palm rhinoceros beetle in the Philippines and in Indonesia. FAO Plant Protection Bulletin 25, 73-77.

Zelazny B. 1980 - Ecology of Cadang-Cadang Disease of Coconut Palm in the Philippines. Phytopathology 70(8), 700-703.

Zelazny B, Niven BS. 1980 - Duration of the stages of cadang-cadang disease of coconut palm. Plant Diseases 64, 841-842.

Zelazny B, Randles JW, Boccardo G, Imperial JS. 1982 - The viroid nature of the cadang-cadang disease of coconut palm. Scientia Filipinas 2, 45-63.

Zelazny B, Pacumbaba E. 1982 - Incidence of cadang-cadang of coconut palm in the Philippines. Plant Dis. 66, 547.

Zelazny B, Lolong A, Pattang B. 1992 - Oryctes rhinoceros (Coleoptera: Scarabaeidae) populations suppressed by a baculovirus. Journal of Invertebrate Pathology 59(1), 61-68.

\section{Disclaimer}

The information presented in this article are the views of the authors and not of the organization they are affiliated with. 